DOI: 10.24234/wisdom.v14i1.319

Nonna KHACHATRYAN,

Hrachya SARGSYAN

\title{
NATIONAL VALUE SYSTEM IMPACT ON THE ECONOMY OF ARMENIA
}

\begin{abstract}
The process of accumulation and economic growth of national wealth has traditionally been linked in theory and in practice to the geographical position of the country, mineral wealth, high-quality human capital, historical events. The article attempts to break this stereotype by linking the country's economic progress with the national value system. To this end, philosophical interpretations of the peculiarities of the Armenian people's national value system are made, analyzing the nation-wide advantages and disadvantages that directly affect the economic progress of the country. In particular, the manifestations of national values that impede Armenia's economic progress are revealed. In this respect, philosophical interpretation is given for Armenians, doing more effectively implement their entrepreneurial skills abroad, rather than in their homeland.
\end{abstract}

Keywords: value system of nations, national entrepreneurial features, "patriotic economics", public and private interests.

\section{Introduction}

For centuries, the economic developments of nations and countries have not been sustained and have had their ups and downs. Some of the once economically powerful countries are now classified as developing nations, or vice versa, a few centuries ago wild tribes and ethnic groups that did not even have statehood, currently included in economically developed countries framework. This phenomenon can be interpreted in several ways. In one case it can be argued, that nations have different speeds of economic development due to the geographical location of their homeland, being located at commercial crossroads, and having seaports. In the other case, the rates of economic development of nations can be correlated with the country's rich mineral re- sources and high-quality workforce presents. The formation of state good neighbourly relations, long-term historical favourable conditions for the development of inter-state relations and vice versa can also have a positive or negative impact on the prosperity of the national economy.

The factors listed certainly have a strong or weak impact on the economic development of any country, but we believe that the value system of nations residing in the country is a priority. Many examples can be found, when several European countries, lacking a rich mineral base and large territories, are currently among the most economically developed countries. On the contrary, some African states, which are rich in mineral resources and have a population of millions, are still unable to provide the necessary economic growth. 
As for Armenia, which only gained independence thirty years ago, it should be noted, that a small state in the region, surrounded by non-fraternal neighbour states, with a poor raw material base, can provide some economic stability. However, we do not think that the factors listed in the economic progress of the Armenian people are the ones that hinder them. Here we hypothesize, that the main reasons for the slow economic prosperity of the Armenian people are hidden in the national value system, where there are harmful components that, cause an economic slowdown. Therefore, our comments on Armenia's economic development opportunities will be viewed in the article through the prism of the national value system.

\section{Research Results}

The nation stands out among other types of socio-ethnic communities as follows. Unlike other socio-ethnic communities, a nation makes out a type of sociality characterized by high mobility of individuals, their lack of attachment to any social positions (more precisely, the possibility of fixing them to some kind of only functional, given that the functionality itself is changeable). The positions themselves can be considered reversible, which paradoxes' the communication between the individuals who occupy them, makes it tautological and uninterrupted. As a result, a new type of individualization (personalization) of the individual is formed, which has historically been reflected in the concept of "personality". Figuratively speaking, this type of personality is problematic for itself. Since the individual is not fixed on any unambiguous social position, and the latter is determined through functional correlation with each other, the individual must organize the whole variety of his functions himself. Due to the fact that he succeeds in self-organization only by distinguishing his position from others, which is in principle, identical and equal to his position, this means the need for a person to affirm himself in communication by contrasting other individuality. But even at the level of analysis of communication, it turns out that for its possibility such affirmation is not enough, it requires something in common for opposed social positions. This results in the fact that the personality itself can be analyzed as a two-part type of individuality, including the unique uniqueness affirmed in the acts of communication, and universality, which makes the positions of communicants comparable (comparable), and theirs similar to each other.

A nation is a value, politically-constructed, discursive type of socio-ethnic communities. The above allows us to formulate methodological provisions regarding the study of national values. The system of national values is complex, multilevel, synchronous and anachronous and cannot be determined a priori - it should be considered as an overlap of the past historical development of the socio-ethnic community, the existing socio-political (and wider the whole social) organization, and specifically communicative as organizing integrity.

Accordingly, in this system, it is possible to distinguish three functionally distinct subsystems that can be considered as levels of ideal objects of national consciousness, the ordering, and configuration of which in any system is historically concrete, and therefore random and unique. The first is ethnic, in which two complex structured elements can be distinguished:

A. basic, with ethnic namely: territory (Fatherland, Motherland), language (mother tongue), stable forms of group consciousness (ethnic mentality, ethnic stereotypes). 
B. concrete-historical, from the point of view of theory, random, but which constitutes proper ethnic (national) history. It includes concrete historical manifestations of ethnoconsolidating and ethno-differentiating processes. It should also include specific manifestations of the ethnos culture (literature, religion, etc.), facts of history (heroes, memorable dates, etc.). The subsystem, as a whole, is connected with the past, serves as the basis for development (social memory).

The third subsystem - the idea of a nation, also manifests itself in two ways: as a value by which subjects are identified, and as an operator in the political space, which ensures the legitimization of private interest as a universal, power/wealth, and, therefore, the orientation of the general action in the desired direction. This subsystem is associated with the future; with goalsetting (design), acting in the form of ideology.

Accordingly, social philosophy in the study of national value should proceed from an analysis of the subject's social interest, determined by his position in the system of social relations. The study itself should be conducted according to the following logical scheme: the subject's position in its interdependence on other positions; resources available to a social group necessary for the formation of their subjectivity (in case of their insufficiency, the definition of social groups dominating over it); the way she posits her subjectivity (i.e., self-identification or identification with another subject); methods and resources of entering into communication systems in which the affirmation of subjectivity takes place (and the reverse is the impact of the communicative system on the ability to access and mobilize resources, restrictions on the methods used), the subject's attitude to the social system as integrity and its place to it.
The typologization of national values, the elucidation of the specific mechanisms of their development, the forms of manifestation in each nation are tasks solved by the methods of specific social sciences. The task of social philosophy in this area is to determine the directions of these studies. Thus, typologization can be carried out according to the method of affirming the value, according to the levels of subjectivity, according to the selection of culturally and historically significant, according to the subjects within the nation. The dynamics of values should be analyzed as the dynamics of intergroup interaction and the dynamics of group interests.

From the socio-philosophical point of view, the main function of national values is recognized as the formation of ideal subjects of national consciousness at all levels. As a form of consciousness, national values are distinguished by complexity, synchronous and anachronous variability and should be considered as the addition of time vectors: the past development of a socio-ethnic community, a real socio-political (and more broadly - the entire social) organization, and the future formed in discursive communication organizing social integrity. The structure of national values includes three components. The first is ethnic, in which two complex structured elements can be distinguished: ethnoforming and concrete historical. The second is socio-organizational, which also includes two elements: substantive, private-group and formaluniversal, political. The third is the idea of a nation, playing a dual role, namely: means of selfidentification of social actors and the operator in the political space.

Despite the multiplicity of the latter, people living in a single socio-cultural and politicalcultural space need a certain set of common values, norms, attitudes, etc. for all of them, which 
together provide the modus Vivendi of all members of society. This complex, which determines the content and orientation of public consciousness, social and political-philosophical thought, can be called a paradigm. The paradigm is understood not as one or another socio-philosophical or other theory or stream of thought, but the fundamental infrastructure of the picture of the social universe, which includes a set of fundamental ideas about society and the individual, civil society and the state, sacred and secular, etc., constituting, as it was the substrate of the most important concepts, theories, and trends of a given historical period. Or, in other words, it constitutes a worldview infrastructure that characterizes space and time, nature and society, man and the state, freedom, and slavery, good and evil, etc.

One of the types of identification strategies of an individual is ethnocultural and national self-identification, the idea of the spiritual unity of an ethnic group based on national values. The identification potential of national values, capable of forming an ethnicity in an individual, is concluded in the fact that national values record the fact of the psychological and social identity of a certain ethnic group and its difference from other similar communities and suggest the unity of all members of a certain ethnic group, united by common ideas, goals, and attitudes. In this regard, national values are not only a combination of psyche traits, needs, interests, attitudes, value orientations, beliefs and ideals of a particular people, which ultimately determine the ethnic character but also act as methods, techniques, and means of achieving goals, forming a specific identification strategy and spiritual and moral principles of all representatives of the nation.

The role of national values in the ethnocultural and national self-identification of the indi- vidual lies in the fact that these values are generally valid and socially significant for all representatives of the ethnos at the same time. National values make it possible to distinguish from the totality of motives, needs, attitudes, orientations, assessments, and opinions of individuals some common and generally significant elements, which, firstly, are supported by an influential set of representatives of a particular nation and, secondly, are of great importance from the point of view of the survival of the nation itself. Ethnocultural and national self-identification of the individual, in turn, involves both the preservation and reproduction of important social relations, resources, ideas, attitudes characteristic of a particular nation, and effective countermeasures in response to destabilizing influences from the outside and as well inside, ensuring the survival of the nation. The internal destabilizing factors in their impact turn out to be much more destructive in their influence on national values, which is primarily associated with the loss of a sense of integrity and the loss of ethnos based foundations of self-identification strategies of representatives of one ethnos (Vildanov, 2014).

The study shows that in general terms the national value system is presented as a set of stereotypes specific to a particular ethnic group, in which the customs and norms of cultural, spiritual, and specific behavioural performance are mutually exclusive. In this respect, the Armenian people, who have a millennium-long history, have inherited a number of value-added components that can have both positive and negative effects on the country's national wealth formation, such as diligence, creativity, and rapid perception of competitive entrepreneurship. Or, an opposite, a lack of perception of corporate economic interest, a deficiency of entrepreneurial collectivism, a shortage of awareness of the need 
for state-run economics, and so on (Tshuguryan \& Khachatryan, 2019).

The national value system of any nation is formed over a long historical period. The Armenian people had lost their statehood as early as the fifth century. Even now, that Armenia has gained independence, it is occasionally preferable for an Armenian businessman to export capital from his own country and start entrepreneurship abroad, as in some cases he may find it more profitable (Tshuguryan, 2018). Guided by the principle that "capital recognizes comfort rather than the homeland", Armenian businessmen often contribute to the development of the economy of foreign countries, bypassing the economic interests of the homeland. Not only is the capital of Armenian businessmen outflowing from the homeland, but the capital of successful Diaspora Armenian businessmen is hardly incoming to Armenia. And the main reason is not the lack of attractiveness of the country's investment environment, but the deficiency of state-owned economy rooted in the national value system of Armenians (Tshuguryan \& Khachatryan, 2019).

In this case, the question arises; what will fill that gap? (Acemoglu \& Robinson, 2009) In our opinion, the Armenian national system needs a well-developed "patriotic economy" settlement. The theory is not considered being the term "patriotic economy", but in general, it can be characterized as an economic process, targeted at the development of the homeland economy.

In our opinion, the key component of the patriotic economy is the public's awareness of the nation's interest and its dedication. In this case, it is already in the subconscious mind of every citizen, apart from the personal interest, to serve the interests of the public economy, which is a powerful and stimulating factor in the eco- nomic progress of one's homeland.

Since independence, when the Armenians centuries-old dream of having a state finally came true, the process of patriotic entrepreneurship in the Republic of Armenia has failed. The exact opposite was done. On the one hand, instead of helping the Republic of Armenia country prosper, Armenian businessmen stole the assets accumulated over decades and privatized during independence, rather than promoting them for active business development. On the other hand, in those years, state officials simply for the sake of self-interest simply wasted a significant portion of grants and aid entering the country, bypassing public interest and thus causing serious economic damage to the homeland. As a result, the capital accumulated in the country began to feel more comfortable abroad, and the rate of emigration increased (Khachatryan, 2018). Instead, significant inflows of international credit entered the country, which began to serve not only the economic growth but only short term macroeconomic stability, thereby increasing the external debt of the Republic of Armenia year by year. Here too, the "patriotic business" did not manifest itself, since the authorities preferred not to exert special efforts in the development of the economy, but merely to ensure economic stability at the expense of external debt at the expiration of its term and a growing debt burden, without worrying that this burden could be a serious obstacle to the future prosperity of the economy.

On the other hand, the pursuit of the "maximum profit of his majesty" pushes Armenian businessmen further away from "patriotic business" (Tshuguryan \& Khachatryan, 2019). In our reality, at least today, the slogan "You must not import what can be produced domestically" should be considered more relevant today, which 
currently largely bypasses the activities of Armenian entrepreneurs. Having large financial funds, they focus more on importing products that are in high market demand than on producing them in the homeland, as the latter is less profitable. Thus, national capital serves the economic interests of foreigners and does not serve the development of the real economic sector of the homeland and the formation of the country's national wealth (Soghomonyan, 2013).

In our opinion, the classification of the impacts of the components of the national value system on the economy of the Republic of Armenia can be implemented in two directions: positive and negative. Components of the positive impact include the hard work of the Armenian people, the high level of creativity in commerce, the flexibility to cope with change, the high degree of resistance to economic stresses, and the emphasis on adaptation to the struggle for business survival. Components of negative impacts may include mono-entrepreneurial aspirations, weak state-run governance orientation, rejection of participatory governance principles, avoidance of entrepreneurial cohesion.

Experience shows that the Armenian entrepreneurs generally rejecting participatory management approaches and seeks mono-management ways (Khachatryan, 2018). Armenians, as a rule, in a business environment trying to govern separately and are unwilling to agree to participate in corporate governance. This problem arises mainly because Armenians in the business sector are reluctant to be included in the participatory management system and generally do not accept compromise options when confronted with conflicts of interest. However, it is wellknown that the current entrepreneurial sector becomes more competitive when it comes to corporate governance when there is harmony between private and group interests. In this situation, naturally, there is no avoidance of entrepreneurial cohesion, which adversely affects not only private business but also the economic growth of the country.

Having been without statehood for centuries, the manifestations of the Armenian national system of values sidestepped by public economic interests, and the weakening of the state-run economy. In this respect, we attach great importance to the revision of the Armenian national value system and the start of the process of selfpurification of the negative components involved, which must first of all be reflected in the upbringing of the individuals.

Researchers believe that today we are witnessing a serious crisis of the world order, which has developed mainly after the second world war. This crisis is exacerbated by a fall in world authority, elites, level of trust in the authorities and the main public institutions (Vardanyan \& Alekyan, 2018). Given this challenge, we believe that the above-described components of the business behaviour of the Armenian people should be re-evaluated.

\section{Conclusion}

The centuries-old national value system has had a significant impact on the economic development of the country. In this regard, we consider it necessary to identify and assess the specific national behavioural risks that may have a negative impact on economic development processes. Consequently, we consider it necessary to interpret not only business education but also the education of the individual related to the risk factors arising from the national value system, which by their nature impede the economic prosperity of the country. In our opinion, the risks to 
the negative impact of the Armenian people's national value system are mono-entrepreneurial aspirations, weak state-run governance, circumvention of the principles of patriotism, rejection of participatory governance principles, avoidance of entrepreneurial cohesion, which can significantly impact the country's economic growth.

\section{REFERENCES}

Acemoglu, D., \& Robinson, J. (2009). Persistence of Power, Elites and Institutions. American Economic Review, 98(1), 121-124.

Khachatryan, N. (2018). Kapitali paxusty' patmakan y'nt'aqy' ev dra kanxargelman ughinery Hayastani Hanrapetut'yunum (The Historical Process of Capital Escape and the Prevention Ways in the Republic of Armenia, in Armenian). Journal, History and Politics, 1(2), 147-152.

Soghomonyan, V. (2013). Haykakan inqnut'yunn $u$ evropakan arjhehamakargy' (Armenian Identity and the European System of Values, in Armenian). Retrieved March 26, 2019 from: http://dis kurs.am/2013/08/109/.

Tshuguryan, A., \& Khachatryan, N. (2019). Economy Development and National Value Interdependence. Journal Hyusisapayl (in Armenia), 5, 41-47.

Tshuguryan, A., (2018, September 19). Tavshya heghapoxut'yuny' ev kapitali p'axusty (Velvet Revolution and Capital Escape, in Armenian). Aravot. Retrieved from: https://www.aravot.am/2018/09/19/981 457/.

Vardanyan, R., \& Alekyan N. (2018). At The Crossroads: Armenia 2041 Project. Retrieved March 26, 2019 from: https://www.reddit.com/r/armenia/com ments/bwtec6/at the crossroads arme nia 2041 project a/.

Vildanov, H. S. (2014). Natsional'nye tsennostiv strukture etnokul'turnoi i natsional'noi samoidentifikatsii individa (National Values in the Structure of Ethno Cultural and National Identity of the Individual, in Russian). The Journal, Basic Research, 9, Retrieved March 26, 2019 from: http://www.fundamental-research . ru/ru/article/view?id=34672. 